\title{
Eksploitasi Loyalitas Penggemar Dalam Pembelian Album K-Pop
}

\author{
Maria Veronica, Sinta Paramita, Lusia Savitri Setyo Utami \\ margarethvero@gmail.com
}

Fakultas Ilmu Komunikasi Universitas Tarumanagara

\begin{abstract}
This research discusses about the exploitation of idol agencies in South Korea towards the loyalty that K-Pop fans have in terms of album purchases. This applies to fans of K-Pop music who are experiencing technological advancements that can simplify the spread of popular culture, giving rise to consumptive behavior about things related to their idols. This research uses the theory of mass communication, mass media, new media, popular culture, fan loyalty and exploitation in the context of popular culture. This research uses a qualitative research methods and is descriptive in nature with methods of collecting in-depth interview data, document review and observation. Exploitation of fan loyalty is carried out by agencies in South Korea by releasing and selling albums with various versions to attract fans. These fans themselves are aware that they have been exploited but their decision to buy and collect albums in large quantities is due to the self-concept that arises because of the emergence of an identity as a fan. They also have a sense of satisfaction when buying albums and as a form to appreciate the works of their idols.
\end{abstract}

Keywords: consumer behaviour, exploitation, fan loyalty, K-Pop, Popular culture.

\begin{abstract}
Abstrak
Penelitian ini membahas tentang eksploitasi yang dilakukan oleh agensi-agensi idola di Korea Selatan terhadap loyalitas penggemar K-Pop dalam hal pembelian album. Hal ini berlaku bagi penggemar musik K-Pop yang mengalami kemajuan teknologi yang dapat mempermudah penyebaran budaya populer sehingga menimbulkan perilaku konsumtif akan hal-hal yang berhubungan dengan idolanya. Penelitian ini menggunakan konsep komunikasi massa, media massa, media baru, budaya populer, loyalitas penggemar dan eksploitasi dalam konteks budaya popular. Penelitian ini menggunakan pendekatan kualitatif dan bersifat deskriptif dengan metode pengumpulan data wawancara mendalam, telaah dokumen dan observasi. Eksploitasi loyalitas penggemar dilakukan oleh agensi-agensi di Korea Selatan dengan cara mengeluarkan dan menjual album dengan beragam versi sehingga menarik minat beli penggemar. Penggemar ini sendiri menyadari bahwa dirinya telah tereksploitasi tetapi keputusan mereka dalam membeli dan mengoleksi album dalam jumlah banyak dikarenakan adanya konsep diri yang timbul karena munculnya identitas sebagai seorang penggemar. Mereka juga mempunyai rasa kepuasaan diri sendiri ketika sudah membeli album dan sebagai bentuk untuk menghargai karya-karya dari idolanya.
\end{abstract}

Kata Kunci: Budaya populer, eksploitasi, K-Pop, loyalitas penggemar, perilaku konsumtif

\section{Pendahuluan}

Perkembangan teknologi saat ini terjadi dengan sangat cepat, terutama dari media-media online yang akan mempermudah kita untuk mencari dan mengakses informasi-informasi yang berasal dari luar. Kemudahan dalam mengakses informasi dari luar tentunya akan semakin mempermudah masuknya budaya populer. Budaya populer ini sendiri mempunyai pengertian, budaya yang secara tidak langsung telah 
mempengaruhi dan mengajak massa untuk terlibat di dalamnya dan penyebarannya yaitu melalui media online. Perkembangan musik dan gaya hidup yang dibawa dari luar tersebut akan membuat orang secara tidak langsung menjadi konsumtif. (http://ejournal.ilkom.fisip-unmul.ac.id/site/wpcontent/uploads/2013/06/Junal\%20Rudi\%20Ganjil\%20(06-01-13-04-50-33).pdf, diakses pada 27 Agustus 2018 pukul 13:25).

Korea Selatan merupakan salah satu contoh negara dengan kebudayaan dan industri hiburan yang sedang digandrungi oleh remaja. Korea Selatan dapat dikatakan telah maju di bidang industri hiburan mulai dari bidang film atau drama, dan musik. Korean Wave adalah pengertian dari tersebarnya budaya pop Korea secara mendunia. Penyebarannya pun bermacam-macam dan sebagian besar dari industri perfilman dan industri musik.

Korea juga dinilai telah sukses memimpin industri hiburan dikarenakan banyaknya peminat dari berbagai dunia yang ingin mengonsumsi musik-musik dari boyband dan girlband-nya. Di Korea Selatan sendiri, penjualan album dibagi menjadi dua jenis, yaitu album fisik dan album digital. Album fisik merupakan album yang berbentuk fisik dan di dalamnya terdapat CD, photobook, photocard, dan merchandise lainnya. Sedangkan album digital merupakan album yang berbentuk file dan diunduh atau dibeli melalui internet. K-Pop pun semakin marak dan menarik penggemar dari berbagai grup untuk membeli serta mengonsumsi merchandise dan album fisik idola K-Pop dengan beragam packaging dan beragam versi. Penggemar dari grup idola Korea tersebut diketahui membeli beragam versi dengan alasan karena ingin mengoleksi dan mengambil photocard untuk kesenangan semata, walaupun lagu di setiap versi itu mempunyai tracklist yang sama (Sumber: http://style.tribunnews.com/2018/07/17/hanya-demi-berburu-photocard-ratusanalbum-wanna-one-ditemukan-dibuang-di-tempat-sampah, diakses pada 27 Agustus 2018 pukul 13:27).

Perilaku konsumtif di kalangan penggemar ini pun dimanfaatkan oleh pihakpihak tertentu untuk mendapatkan keuntungan. Loyalitas dari penggemar di sini dijadikan sebagai nilai jual. Loyalitas yang dimiliki oleh penggemar itu pun memicu adanya proses eksploitasi. Eksploitasi menurut Marx merupakan suatu istilah yang secara sederhana menjelaskan suatu perbuatan pemanfaatan titik lemah satu pihak oleh pihak lain sebagai alat untuk meraih tujuannya sendiri dengan biaya (expense) dari pihak yang dimanfaatkan tersebut. Eksploitasi dapat terjadi dalam berbagai bentuk, salah satu contohnya adalah eksploitasi yang melibatkan loyalitas penggemar. Loyalitas yang dimiliki penggemar di sini dijadikan sebagai alat untuk mendapatkan keuntungan dan dimanfaatkan untuk kepentingan ekonomi sematamata dari pihak manajemen artis (http://repository.untar.ac.id/427/1/1978-4298-1PB.pdf, diakses pada 14 September 2018 pukul 17:40).

Penjualan album merupakan mata pencaharian utama idola di Korea, di samping kemenangan awards dan konser tur dunia. Tidak sedikit juga mereka merilis album fisik dengan berbagai versi yang dapat menarik penggemar untuk membeli dan mengkoleksi semua versi tersebut. Loyalitas dari penggemar masingmasing idola secara tidak langsung akan meningkatkan industri penjualan CD dan menjadikan Korea sebagai negara tersukses di bidang hiburan. Loyalitas penggemar dijadikan sebagai bahan eksploitasi untuk mendatangkan keuntungan bagi pihakpihak tertentu dan hal itu dinilai cukup berhasil. Dengan melihat wabah Korean Wave yang dikatakan sangat populer terlebih lagi di kalangan remaja Indonesia, peneliti ingin meneliti lebih dalam mengenai fenomena pembelian album fisik K-Pop 
yang dilakukan oleh penggemar di Indonesia. Oleh sebab itu peneliti membuat skripsi dengan mengangkat judul "Eksploitasi Loyalitas Penggemar Dalam Pembelian Album K-Pop".

Penelitian ini diharapkan dapat bermanfaat untuk pengembangan Ilmu Komunikasi khususnya dalam bidang kajian budaya popular dan dapat memberikan wawasan tentang bagaimana pengaruh dari Korean Wave yang telah mempengaruhi gaya hidup konsumtif penggemar K-Pop di Indonesia. Penelitian ini juga diharapkan dapat memberi gambaran tentang bagaimana eksploitasi loyalitas penggemar K-Pop dalam pembelian album fisik K-Pop, serta dapat memperluas sudut pandang penggemar K-Pop di Indonesia dalam mengkonsumsi budaya populer yang ditayangkan oleh media dengan lebih kritis.

\section{Metode Penelitian}

Peneliti menggunakan pendekatan kualitatif karena berguna untuk mendapatkan hasil yang lebih akurat dalam suatu masalah. Dengan menggunakan pendekatan kualitatif dalam penelitian ini, peneliti dapat mengetahui lebih dalam tentang bagaimana eksploitasi loyalitas penggemar dalam pembelian album K-Pop.

Menurut Sugiyono (2016), metode penelitian kualitatif adalah metode penelitian yang digunakan untuk meneliti pada kondisi obyek yang bersifat alamiah, dimana peneliti sebagai instrumen kunci, teknik pengumpulan dilakukan secara trianggulasi, analisis data bersifat induktif, dan hasil penelitian kualitatif lebih menekankan makna daripada generalisasi. Dalam penelitian kualitatif para peneliti mencari makna, pemahaman, pengertian tentang suatu fenomena, kejadian maupun kehidupan manusia dengan terlibat langsung atau tidak langsung. Peneliti dalam penelitian kualitatif akan memahami makna suatu peristiwa dengan mencoba berinteraksi dengan orang-orang dalam situasi tersebut (Yusuf, 2014). Dengan menggunakan metode penelitian kualitatif, peneliti berusaha untuk menjelaskan dan mendeskripsikan bagaimana loyalitas penggemar dieksploitasi oleh agensi-agensi idola di Korea dalam hal pembelian album K-Pop.

Pada penelitian ini, peneliti menggunakan jenis penelitian kualitatif deskriptif dengan strategi penelitian fenomenologi. Penelitian fenomenologi adalah ilmu-ilmu tentang fenomena yang menampakkan diri dari kesadaran peneliti. Jika diartikan secara luas, fenomenologi adalah ilmu tentang gejala atau hal-hal apa saja yang kelihatan. Fenomenologi merupakan salah satu bentuk penelitian kualitatif yang tumbuh dan berkembang dalam bidang sosiologi, menjadikan pokok kajian fenomena yang tampak sebagai subjek penelitian, namun bebas dari unsur subjektivitas peneliti (Yusuf, 2014). Peneliti dalam penelitian kualitatif akan mendalami makna suatu kejadian peristiwa dengan cara berinteraksi dengan orangorang dalam suatu fenomena.

Dalam penelitian ini, peneliti memilih penggemar untuk menjadi subjek penelitian, sedangkan untuk objek penelitiannya adalah loyalitas penggemar yang sudah dieksploitasi menjadi obyek penelitian. Metode pengumpulan data yang digunakan dalam penelitian ini adalah observasi, wawancara mendalam terhadap lima narasumber dan telaah dokumen. Demi mendapatkan data yang lebih lengkap, peneliti mengumpulkan berbagai sumber data dan informasi dari buku-buku dan jurnal-jurnal yang terdapat di perpustakaan dan dari sumber online sehingga menghasilkan data yang lengkap dan relevan. Data yang sudah terkumpul melalui 
berbagai buku-buku dan jurnal-jurnal tersebut kemudian akan menjadi data sekunder untuk melengkapi hasil penelitian.

Menurut Emzir (2014) analisis data adalah proses sistematis pencarian dan pengaturan transkrip wawancara, catatatan lapangan dan materi-materi lain yang telah dikumpulkan peneliti untuk meningkatkan pemahaman peneliti mengenai materi-materi tersebut serta memungkinkan peneliti untuk menyajikan apa yang sudah ditemukan selama penelitian kepada orang lain.

Dalam penelitian ini, peneliti menggunakan teknik analisis data kualitatif model Miles dan Hubermen. Dalam penelitian ini teknik pemeriksaan keabsahan data yang peneliti gunakan adalah triangulasi data. Dengan menggunakan triangulasi, peneliti dapat memeriksa kembali temuannya dengan cara membandingkan dengan berbagai sumber, metode atau teori. Dalam penelitian ini peneliti menggunakan triangulasi metode, yaitu dengan melakukan pengecekan hasil penelitian dengan teknik yang berbeda-beda yaitu seperti wawancara, observasi, dan dokumentasi untuk mendapatkan hasil yang valid (Moleong 2012).

\section{Hasil Temuan dan Diskusi}

Setelah melakukan observasi di lapangan dan melakukan wawancara dengan beberapa narasumber, penulis menemukan beberapa hal menarik:

\section{Loyalitas Penggemar}

Media baru yang merupakan pengembangan dari media massa akan mempermudah pengaksesan informasi melalui internet dan akan memudahkan masuknya sebuah budaya popular. Budaya populer pada dasarnya merupakan budaya yang digemari masyarakat dan akan dikonsumsi secara luas. Budaya tersebut sedang digandrungi oleh masyarakat terutama di kalangan anak muda yang paling populer adalah munculnya budaya Korean Wave dan K-Pop. Dengan adanya K-Pop, muncul berbagai budaya seperti musik, drama, gaya hidup dan bahasa. Massa yang telah terlibat di dalam budaya populer K-Pop ini akan mempunyai sifat fanatik terhadap idolanya dan menjadi konsumtif. Seseorang yang mempunyai perilaku tersebut biasanya disebut penggemar. Penggemar yang fanatik akan mempunyai rasa untuk ingin mengkonsumsi segala hal yang berhubungan dengan idolanya dan perlahanlahan akan membentuk suatu perilaku konsumtif.

Perilaku konsumtif yang muncul dari penggemar secara tidak langsung akan membentuk sebuah loyalitas dimana penggemar akan rela merogoh kocek uangnya demi sang idola. Penggemar yang loyal merupakan aset penting bagi setiap idola di Korea. Hal ini dapat dilihat dari tingkatan pelanggan menuju loyalitas sebagaimana yang dikemukakan oleh Syafruddin Chan (dalam Hurriyati, 2010:135) bahwa penggemar masuk ke dalam tingkatan pelanggan kategori emas. Kategori emas merupakan kelompok pelanggan yang memberikan keuntungan terbesar kepada suatu perusahaan. Biasanya kelompok ini selalu membeli dalam jumlah yang besar dan frekuensi pembeliannya sangat tinggi. Pelanggan disini tidak peduli dengan harga dan tidak segan juga untuk mengeluarkan uangnya untuk sesuatu yang ingin dinikmatinya.

Menurut Stanley A. Brown (dalam Hurriyati, 2010:138), loyalitas pelanggan memiliki tahapan sebagai berikut: 


\section{The Courtship}

Pada tahap ini hubungan yang terjalin antara perusahaan dengan pelanggan terbatas pada sebuah transaksi. Pelanggan masih akan mempertimbangkan produk dan harga. Dalam tahap ini, penggemar masih akan mempertimbangkan pembelian album berdasarkan harga-harga yang dimiliki oleh tiap album.

\section{The Relationship}

Pada tahapan ini tercipta hubungan yang erat antara perusahaan dengan pelanggan. Loyalitas yang terbentuk tidak lagi berdasarkan pertimbangan harga dan produk, selain itu pada tahapan ini akan terjadi hubungan saling menguntungkan bagi kedua belah pihak. Dalam tahapan ini, penggemar dan idolanya akan saling mendapatkan keuntungan masing-masing. Bagi idolanya sendiri, mereka akan mendapatkan sebuah pendapatan yang tinggi serta mencapai puncak tertinggi pada chart penjualan album pada portal musik Korea apabila albumnya terjual banyak. Bagi penggemar, mereka akan mendapatkan suatu keuntungan yaitu kepuasan bagi diri sendiri dalam membeli album karena keinginan mereka yang besar dalam mengoleksi photocard yang ada di dalam album tersebut.

\section{The Marriage}

Pada tahapan ini hubungan jangka panjang telah tercipta dan keduanya tidak dapat dipisahkan dan loyalitas terbentuk karena adanya tingkat kepuasan yang tinggi. Pada tahapan ini juga loyalitas akan tercipta karena kepuasan terhadap perusahaan dan ketergantungan pelanggan tersebut. Loyalitas yang dimiliki oleh penggemar pasti akan membentuk suatu tindakan untuk membeli dan mengoleksi album dari idolanya. Bahkan beberapa penggemar K-Pop bisa menghabiskan uang sampai puluhan juta demi kecintaannya terhadap idolanya tersebut.

Eksploitasi Loyalitas Penggemar Dalam Konteks Budaya Populer

Penggemar yang telah menghabiskan uangnya dalam membeli album idola $\mathrm{K}$ Pop bisa dikatakan sudah memiliki sifat loyal yang perlahan-lahan tidak disadari bahwa dirinya sudah dieksploitasi secara tidak langsung. Dengan adanya kegiatan tersebut, eksploitasi terjadi dan hal itu dimanfaatkan oleh pihak-pihak tertentu yang sebenarnya menyerang pihak yang lemah dan tidak tahu bahwa sedang dimanfaatkan. Park Jin Young selaku CEO dari agensi Korea Selatan yakni JYP Entertainment dalam seminarnya yang berjudul 'JYP 2.0' (2018) menyatakan bahwa untuk mengukur suatu kesuksesan dalam berindustri di bidang musik K-Pop adalah dari segi penjualan album fisik. Melihat pernyataan Park Jin Young selaku CEO dari JYP Entertainment sudah cukup jelas bahwa mereka selaku pihak agensi sangat mengetahui bahwa seorang penggemar yang mempunyai sifat loyalitas tinggi pasti akan membeli album dari idolanya tersebut dan hal itu secara tidak langsung akan membawa keuntungan berupa pendapatan yang sangat besar bagi agensi. Hal ini juga secara tidak langsung dapat menyatakan bahwa agensi-agensi idola di Korea telah memanfaatkan dan mengeksploitasi loyalitas yang dimiliki penggemar demi keuntungan ekonomi semata. 
Eksploitasi yang dimaksud di sini adalah eksploitasi ekonomi di mana keadaan ekonomi yang dimiliki oleh penggemar akan dimanfaatkan demi keuntungan sepihak (Rukhsal, 2015). Agensi dari idola-idola di Korea Selatan mengetahui bahwa seorang penggemar yang sangat mencintai idolanya pasti akan rela berbuat loyal demi idolanya tersebut. Eksploitasi menurut Marx sendiri merupakan suatu istilah untuk menjelaskan suatu perbuatan pemanfaatan titik lemah satu pihak oleh pihak lain sebagai alat untuk meraih tujuannya sendiri dengan biaya (expense) dari pihak yang dimanfaatkan tersebut (Utami, 2015).

Di Korea Selatan sendiri banyak agensi idola-idola K-Pop yang bersaing dalam hal penjualan album fisik. Penggemar berat boygroup dan girlgroup K-Pop rata-rata akan menghabiskan uangnya untuk membeli dan mengoleksi album dari sang idola dengan jumlah yang banyak dan berversi-versi. Agensi-agensi idola K-Pop saat ini sengaja mengeluarkan album dengan banyak versi yang bonusnya berbeda-beda di setiap albumnya, dan dimana album tersebut akan berisikan bonus-bonus seperti photocard, photobook dan stiker yang berbeda-beda modelnya sehingga penggemar ingin membeli berbagai versi sebagai barang koleksi mereka.

Dari beberapa jawaban narasumber, mengenai agensi yang mengeluarkan album dengan versi berbeda-beda tersebut merupakan sebuah teknik marketing yang memanfaatkan loyalitas dari penggemar itu dan menjadikan penggemar sebagai mata pencaharian utamanya. Banyak penggemar yang menyatakan bahwa mereka senang untuk mengoleksi dan membeli album dari idolanya tersebut. Beberapa narasumber juga mengungkapkan bahwa sebenarnya mereka tidak menyadari tindakan dari agensi yang seperti itu telah mengeksploitasi loyalitas yang dimiliki oleh penggemar.

Keputusan seorang penggemar untuk membeli album dan tidak menyadari adanya pemanfaatan oleh agensi-agensi idolanya yang dilakukan demi keuntungan ekonomi dan telah membentuk sebuah eksploitasi didasarkan karena adanya identitas diri sebagai penggemar. Mereka merasa bahwa dengan membeli dan mengoleksi album dari idolanya itu patut dilakukan karena mereka beranggapan bahwa hal itu sudah menjadi kewajiban untuk seorang penggemar. Adanya identitas diri yang muncul di dalam diri seorang penggemar juga dipengaruhi oleh konsep diri. Ketika penggemar mempunyai perasaan dan berhubungan dengan suatu objek, maka mereka akan merasa menjadi seperti yang dituangkan ke dalam objek yang mereka beli (Purwitasari, 2014).

Menurut Hawkins dalam bukunya yang berjudul Consumer Behavior: Building Marketing Strategy (2013), manusia lebih banyak menghabiskan waktu untuk membeli dan mengkonsumsi sesuatu daripada bekerja atau beristirahat. Kita sebagai manusia di dalam hidup ini pasti ada mengonsumsi produk untuk memuaskan diri sendiri seperti mobil atau yang berhubungan dengan dunia hiburan seperti televisi atau konser. Dari adanya pernyataan Hawkins, dapat dilihat bahwa penggemar ini memang mempunyai suatu konsep diri dimana ketika ia merasa mempunyai citra diri sebagai penggemar, maka ia memang sudah seharusnya untuk mengkonsumsi album tidak peduli berapa pun uang yang telah dihabiskan.

\section{Simpulan}

Seorang penggemar K-Pop yang sudah mempunyai rasa kecintaan berlebih terhadap idolanya akan membeli album dalam jumlah banyak dan dengan berbagai versi sebagai rasa kepuasan untuk diri sendiri dan juga untuk membantu penjualan album sang idola. Perilaku penggemar ini sendiri telah membentuk sebuah loyalitas 
yang dimanfaatkan oleh setiap agensi idola di Korea untuk meraup keuntungan sebanyak-banyaknya dan dapat memperlihatkan bahwa penggemar sudah dieksploitasi secara tidak langsung.

Penggemar yang menyadari bahwa dirinya telah dieksploitasi, sama sekali tidak mempermasalahkan karena adanya rasa kecintaan terhadap idolanya yang telah tumbuh besar di dalam dirinya. Fenomena agensi yang telah mengeksploitasi daya beli seorang penggemar melalui album berbagai versi juga merupakan sebuah teknik marketing agar artisnya tersebut mendapatkan sebuah prestasi dalam penjualan album. Penggemar merasa bahwa dengan membeli dan mengkoleksi album dari idolanya wajib dilakukan, karena mereka beranggapan bahwa hal tersebut merupakan hal yang seharusnya dilakukan oleh seorang penggemar. Identitas diri seorang penggemar ini juga muncul karena adanya konsep diri dimana ketika ia mempunyai citra diri sebagai penggemar, maka memang sudah kewajiban untuk mengkonsumsi album tidak peduli berapa pun uang yang telah dihabiskan.

\section{Ucapan Terima Kasih}

Ucapan terima kasih penulis berikan kepada semua narasumber yang telah bersedia untuk meluangkan waktunya dan memberikan informasi kepada peneliti selama proses pengumpulan data dalam penelitian ini. Peneliti juga ingin mengucapkan terima kasih kepada Fakultas Ilmu Komunikasi Universitas Tarumanagara.

\section{Daftar Pustaka}

Emzir. (2014). Metodologi Penelitian Kualitatif: Analisis Data. Jakarta: Rajawali Pers.

Hawkins, Del. I; Mothersbaugh, David. L. (2013). Consumer Behavior: Building Marketing Strategy (Twelfth Edition). New York: McGraw-Hill.

Hurriyati, Ratih. (2010). Bauran Pemasaran dan Loyalitas Konsumen. Bandung: CV Alfabeta Bandung.

Moleong, Lexy J. (2012). Metodologi Penelitian Kualitatif. Bandung: PT Rosdakarya.

Purwitasari, Florensia Yunia Dian Isa. (2014). Analisis Fenomenologi Reprentasi Konsep Pria Dalam Iklan Televisi (Studi Pada Iklan Televisi Vaseline Men Wash Moisturizer Versi Naik Motor dan Men's Biore Versi Main Bola). Universitas Katolik Unika Soegijapranata: Fakultas Ekonomi dan Bisnis. (http://repository.unika.ac.id/424/3/11.32.0005\%20Florensia\%20Yunia\%20Dia n\%20Isa\%20Purwitasari\%20BAB\%20II.pdf).

Rukhsal, Syarifah Qurrata Ayyun Kusumaningsih. (2015). Faktor-Faktor Penyebab Eksploitasi Secara Ekonomi Terhadap Anak Jalanan Dalam Perspektif Hukum Perlindungan Anak (Studi di Kota Malang). Universitas Brawijaya: Fakultas Hukum. (http://hukum.studentjournal.ub.ac.id/index.php/hukum/article/view/989/978).

Setiawan, Rudy. (2013). Kekuatan New Media Dalam Membentuk Budaya Populer di Indonesia (Studi Tentang Menjadi Artis Dadakan Dalam Mengunggah Video Musik Di Youtube). Vol 2. No 1. Universitas Parahyangan: Fakultas Ilmu Sosial dan Politik. (http://ejournal.ilkom.fisip-unmul.ac.id/site/wp- 
content/uploads/2013/06/Junal\%20Rudi\%20Ganji1\%20(06-01-13-04-5033).pdf).

Sugiyono. (2016). Metode Penelitian Kuantitatif, Kualitatif dan Kombinasi (Mixed Methods). Bandung: Alfabeta.

TribunNews. (2018). Hanya Demi Berburu Photocard, Ratusan Album Wanna One Ditemukan Dibuang di Tempat Sampah

(http://style.tribunnews.com/2018/07/17/hanya-demi-berburu-photocardratusan-album-wanna-one-ditemukan-dibuang-di-tempat-sampah?page=2)

Utami, Lusia Savitri Setyo. (2014). Eksploitasi Seksualitas Dalam Koreografi Di Korean Pop Music Video (Studi Semiotika Pada 'Marionette' dan 'A.D.T.O.Y'). Universitas Tarumanagara: Fakultas Ilmu Komunikasi. (http://repository.untar.ac.id/427/1/1978-4298-1-PB.pdf).

Yusuf, Muri. (2014). Metodologi Penelitian Kuantitatif, Kualitatif \& Penelitian Gabungan. Jakarta: Prenadamedia Group. 